\title{
Correction to: Biostratigraphy of the Kazhdumi Formation (Albian), northeast of Shiraz, Zagros Basin (SW of Iran)
}

\author{
Massih Afghah ${ }^{1} \cdot$ Mahnaz Parvaneh Nejad Shirazi $^{2} \cdot$ Mojtaba Keshavarzi $^{2}$
}

Published online: 24 December 2020

c) Springer-Verlag GmbH Germany, part of Springer Nature 2020

\section{Correction to: Carbonates and Evaporites (2020) 35:103 https://doi.org/10.1007/s13146-020-00635-z}

The article "Biostratigraphy of the Kazhdumi Formation (Albian), northeast of Shiraz, Zagros Basin (SW of Iran)", written by Massih Afghah · Mahnaz Parvaneh Nejad Shirazi and Mojtaba Keshavarzi, was originally published online on 29 September 2020 with Open Access under a Creative Commons Attribution 4.0 International License. After publication in volume 35 , issue 4 , page 1-10 the author(s) decided to cancel the Open Access. Therefore, the copyright of the article has been changed on 06 November 2020 to (C) Springer-Verlag GmbH ermany, part of Springer Nature 2020 with all rights reserved.

The original article can be found online at https://doi.org/10.1007/ s13146-020-00635-z.

Massih Afghah

massihafg2002@yahoo.com

1 Department of Geology, Shiraz Branch, Islamic Azad University, Shiraz, Iran

2 Geology Department, Payame Noor University, PO Box: 19395-3697, Tehran, Iran
Publisher's Note Springer Nature remains neutral with regard to jurisdictional claims in published maps and institutional affiliations. 